(Réplaces Letter Circular 474)

Revised to Feb. $\$, 1938$.

\title{
SOURCES OF RADIO INFORIMATION
}

\section{Contents}

1. Periodicals

2. Books

3. U.S.Government radio publications

4. Publications of the International Bureau of the Telecommunication Union, Berne, Switzerland.

5. Radio laws and regulations

6. Safety rules.

\section{Periodicals}

The following is a partiol list of periodicals largely devoted to radio. They are monthly, except. Where otherwise stated. A number of electrical and general magazines also publish considerable radio information.

A classified list of the articles of radio engineering interest appearing in periodicals is published each month in the Bri-. tish magazine listed below, Wireless Engineer. A short abstract of each article is given.

Proceedings of the Institute of Radio Engineers, 330 West $42 n d$ st., New York, N.Y. (Technical).

Bell System Technical Jaurnal. Published by American Telephone and Telegraph Co., 195 Broadway, New York, N.Y. (Technical) (Quarterly).

QST. Published by American Radio Relay League, West Hartford, Conn. (Technical).

Al1-Wave Redio. Manson Publishing Corp., 16 E. 43d St., New York', N.Y. (Semi-technical). 
Electronics. McGraw-Hill Publishing Co., Inc., $330 \mathrm{~W}$. 42nd st.. New York, N.Y. (Technical).

Communications. Bryant Davis Lublishing Co., 19 E. 47 th St., New York, N.Y. (TechnicaI).

RCA Review。 RCA Institutes Technical Press, 75 Varick st., New York, N.Y. (Technical).

RVIA Engineer. Engineering Division, Radio Manufacturers Association, 1317 National Press Blde., Washington, D. C. (Technical).

Radio News and Short-Wave Radio. 461 Eighth Ave, New York, N.Y. (Semi-technical)。

Radio. 7460 Beverly Blvan, Los Angeles, Calif。 (Technical).

Short Wave end Television. Fopular Book Corp., 99-101 Hudson St., New York, N.Y. (Semi-technical).

Radiocraft. Radiocraft Fublications, Inc., 99 Hudson St., New York, N.Y. (Semi-technical)。

Radio Digest. 7460 Beverly Blva., Los AnEeles, Calif. (Technical).

General Radio Experimenter. Published by General Radio Co., 30 state st., Cambridee, Mass. (Trade, technical).

Radio Retailing. Published by MeGraw-Hill, Publishing Co, Inc., $330 \mathrm{~W}, 42 \mathrm{nd}$ St., New York, N.Y. (Trade)。

Radio Today. Caldwell-Clements Inc., 480 Lexington Ave., New York, N.Y. (Trade).

Wireless Engineer. Published by Iliffe \& Sons, Ltd., Dorset House, Stamford St., London, S.E.I, England. (Téchnical).

Marconi Review。 Marconi's Wireless Telegraph Co., Lt.d.., Electra House, Victoria Embankment, London, Encland. (Technical).

Wireless World. Dorset House, Stamford St., London, S.E. I, England. (Semi-technical)' (Weekly).

Elektrische Nachrichten-Technik. Published by Weidmannschen

Buchhandlung, Berlin S.W.68, Germany. (Technical; in German).

Hochfrequenztechnik und Elektroakstik. (also called Jahrouch der Drahtlosen Telegraphie und Telephonie)。 Published by $\mathbb{M}$. Krayn, Genthiner Strasse 39, Berlin W10, Germany. (Technical; in German). 
L!Onde Electrique. Published by E. Chịrnn, 40 rue de seine, . Paris, France. (Technical; in Frencin.)..

\section{Books}

Herewith are listed $\dot{a}$ few of the many books published on the various phases of radio. Under each, subject the books are in chronological oraer. As a matter of convenience, the prices of some of these books ere given, but the Bureau can not be responsible for the accuracy of this information.

The sources of Government publications on radio àre described in section 3 below.

\section{Radio Principles}

Signaling through space without wires. Sir oliver Lodge. 1894. Electrician Eublishing Co., London, England.

Electric waves. H. Hertz. igco: English translation by D. E. Jones, Macmilian \& Co., $60^{\circ}$ - 5 th Avenue, Néw York, N.Y.

Principles of wireless.telegraphy. G. W. Pierce. 1910. McGrawH111 Book Co., Inc., 330 West 42nd St., New York, N. Y.

Principles underlying radio communication. '2nà edition. 1922. Signal Corps Radio Communication Pamohlet No. 4C. Obtainable from the. Superintendent of. Documents, Government Printing Office, Washington, D.G. \$1.00.

Radis telephony for amateurs. S. Ballantine: 1922. David McKay Co, Fhiladelphịa, Pr.

The radio manual. O: E. Dunlap, Jṛ. 1924. Houghton-Mifflin Co., Cambriage, Mass.

Practical radio. Moyeṛ a Wostrel. 1926. NcGraw-Hill Book. Co., Inc., 330 W. 42nd. St., New York, N.Y.

Fundamentals of radio. J. I. Thomas. 1927. D. Van Nostrand Co., 250 Fourth Ave., New York, N.Y. 夷I.50.

Robison's manual of radio telegraphy and telephony. 1927. Unitea States Naval Institute, Annapolis, Ma. \$4.00.

Propagation of wireless waves.. P. Pedersen. 1927. Vimmelskaftet, Copenhagen, Denmari. 
Radio engineering principles. Lauer \& Brown.: 2nd edition. 1927. MeGraw-Hill Book Co., Ine., 330 W. 42nd St., New York, N.Y. \$3.50. Principles of modern radio receiving. L. G. Hector. 1927. Burton Publishing Co., Bigelow BIdg., Buffalo, N.Y.

The outline of radio. J.V. L. Hogan. 1928. Little, Brown \& Co., Boston, Mass.

Wireless principles nd practice. L. S. Palmer. 1928. Longmans, Green \& Co., Ner York, N.Y.

The radio menual. G. Sterling. 1929. D. Van Nostrand Co., 250 Fourth Ave., New York, N.Y. \$6.00.

I.C.S. Handbook for radio operators. 1929. International Correspondence Schools, Scranton, Pr.

Elements of radio conmunication. J. H. Morecroft. 1929. John Wiley \& Sons, Inc., 440 Fourth Ave., New Yort, N.Y. \$3.00.

Rediotelégraphy and teléphony. Duncen ard Drew. 1929. John Miley \& Sons, Inc., 440 Fourth Avenue, New York, N.Y. \$7.50.

Foundations of radio. R. 'L. Duncan. 1931. John Wiley \& Sons, Inc., 440 Fourth Ave., New York, N.Y. s2.50.

Experimental redio encineering. J. H. Morecroft. 1931. John Wiley \& Sons, Inc., 440 Fourth Ave., New York, N.Y. 菅3.50.

The radio hendhook. J. A. Moyer and J. F. Wostrel. 1931. John Wiley \& Sons, Inc., 440 Fourth Ave., New York, N.Y. $35.5,0$.

Radio elementary principles. E. M. Burns. 1932. D. Tan Nostrand Co., New York, N.Y. \$2.CO.

Elementary principles of wireless telegraphy. R. D. Bangay. Revised by 0. F. Bromn. 1933. Iliffe \& Sons, Lta., Dorset House, Stamford st., London, S.E.I, England. Price Ios.6a.

Principles of redio communication. J.' Horecroft. 1934. 3d edition. John Wiley \& Sons, Inc., 440 Fourth Avenue, New York, N.Y. \$7.50.

Radio engineering hridbook. K. Henney. 2d edition. 1935. McGraw-Hill Book Co., Inc., 330 W. 42nd st., New York, N.Y. $\$ 5.00$. 
$20513 \ldots 218138$.

The book of practicel radio. John Scott-Taggart. 1935. Wireless and Television Review, Cobbs Court, Broedway, London, E.C.4, England.

Practical redio communication. A。 Ril Nilson and J. L. Horning. 1935. McGram-Hill Book Co., 330 . Land St., New York, N.Y. 事5.00.

Phenomena in high-frequency systems. A. Hund. 1935. MoGrem-Hill Book.Co., 330 W. 42nd St:; New York, N.Y.

The fundamentals of radio. R. R. Ramsey. 2nd edition. 1935. Bloomington, Ind. $\$ 3.50$.

Princibles of radio engineering. R. S. Glesgow. 1936. McGrawaHill Book Co., $330 \mathrm{~W}$. 42nd St., New York, N.I. \$ 4.00 .-

Foundations of wireless. A.L.M.Somerby. 1936. Iliffe \& Sons Lta., London. $4 \mathrm{~s} .6 \mathrm{a}$.

Vireless telegraphy -.. Notes for students. 1936. Pitmen Pub'Iishirg Corp., 2 W. 45 th St., New.York, N.Y. s2.25.

Radio receiving and television tubes. J.A. Moyer snd J. F. Wostrel. 1936. 3d edition. McGraw-Hill Book Co., $330 \%$. 42nd st., New York, N.Y. \$4.00.

Communication and electronics (Electrical Engineer's Handbook). H. Pender and $\mathrm{K}$. McIlmaine. 1936. John Wiley \& Sons, 440 Fourth Ave., New York, N.Y. \$5.00.

Radio physics course. A. A. Gheraidi. 2nd edition. 1936. Radio Technical Publishing. Co., 45 Astor Blace, Mew York, N.Y. \$4.00.

Communicetion engineering. W. L. Everett. 2nd edition. 1937. McGraw-Hill Book Co., Inc., 330 West 42nd St., New York, N. Y. $\$ 5.00$.

Redio engineering. F. T. Terman. 2nd edition. 1937. MeGrewHill Book Co., Inc., 330 W. 42nd St., New York, N.Y. \$5.50.

Experimental radio. 4th ed. 1937. R. R. Ransey. Bloomington, Ind。覀2.75。

Principles of radio. Keith Henney. 3d edition. 193\%. John Wiley \& Sons, Inc., 440 Fourth Ave., Nem Vork, N.Y. \$3.50. 


\section{Hich Freduencies}

Ler udes electriques courtes (short electric waves). R. Mesny. 1927. Les Dresses Universitaires de France, 40 Boulevard

Saint Michel, Paris, France.

Short waves: C. R. Leutz and R: B. Gabile. 1930. C. R. Leutz Inc., AItoona, Pa。弗3.00。

Below 10 meters. 1932. National Co., Malden, ilass. 50 .

The manuel of short wave radio.? volumes. 1932. National Co., Maldén, Mass. $50 \not k$ each pàmphlet.

Hochfrequenztechnik in der Luftehit (High-frequency technique in aircraft). H. Fassbender. 1932. J. Springer, Unter den Linden, Berlin'Ni7, Germèny. $6 \& \mathrm{RM}$

Hoit to build and operate short wave récivers. 1933. Published by Short Wave Craft, 96-98 Park Place, Nem York, N.Y. 50́d.

The radio amateur's hanabook. A. F. Collins and G. C. B. Rome. 7th edition: 1933. Thomas Y. Crowell Co., 393 - 4th Ave., Nert York, N.Y.

Short wave radio hendbook." C. E. Denton. Radio and Technicai

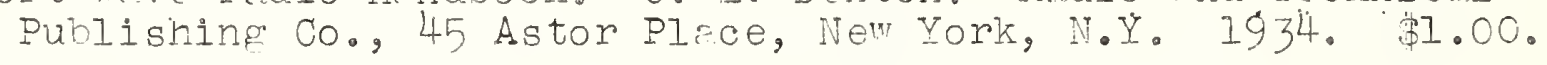

Kruse's radiophone guide. 2d edition. 1934. R. S. Kruse.

Published by R. S. Kruse, Guilford, Conn. 50d. ..

World short-Wave radiophone transmitters. Me. I 15, 1935. Buresu of Eoreign and Domestic Commerce, Dept: of Commerce, Washington, -D.C. $25 \notin$ :

A guide to reception of short-wave bropdcesting stations. Burenu of'Foreich and Domestic Commerce, Dept. of Commee, Weshington, D.C., 1936. 25ф.

Physik un Technik der Ultrokurzen Vellen. H. Hollmann.

lst Band-Trzejeung ultrekurzwelliger schwingungen (physics and Engineering Development of Ultre-Short Woves - Fol.1 - Generntion of ultra-short wave oscillations): J. Springer. 1936. 36 R.M.

Short wrve wireless communication. A. W. Ladner and C. R. Stoner. 1937. 3a edition. John Wiley \& Sons, Inc., 440 Fourth Ave., New York, N.Y. $\$ 4.50$. 
The radio amateur's handbook. 1938. American Radio Relay League, W. Hartfora, Conn., 弗1.00。

"Radio" hendbook. 1938. Radio, 7460 Beverly Blva., Los Angeles, Calif。 \$1.50.

Radio telephony handbook. .193\%. Radio, 7460 Eeverly BIva., Los Angeles, Calif. $75 d$.

Radio antenna handbook. 1938. Radio, 7460 Beverly BIvd., Los Angeles, Calif. $75 \phi$.

Radio amateur 'nemcomer's, handbook. 1938. Radio, 746n Beverly Blva., Los Angeles, Calif. 35d.

"Radio" noise reduction handbook. 1938. Radio, 7460 Beverly Blva., Los Angeles, Calif. 350 .

"Radio" ultra-high frequency handbook. 1933. Radio, 7460 Beverly Blvd., Los Angeles, Calif: :50ф.

How to become a radio amateur. 1938. American Rodio Relay League, W. Hertford, Conn. 25ф.

The radio ameteur's license manual. 1938. American Radio Relay Lergue, $\%$. Hártford, Conn. 25d.

Building an amateur radiotelephone. 1938. Americen Radio Relay League, W.Hertiord, Conn. $25 \phi$.

Radio mateur course. 1938. Short Wave \& Television, 99 Hudson st., New York City.' $50 \notin$.

Short wave coil date book. 1938. Radio Publications, 97 Hudson st., New York City. 25ф.

Radio Measurements

Prepared radio mensurements with self-computing charts. Relph Batcher. 1921. Wireless Press, Inc., 326 Broadway, New York, N.Y.

Radio-frequency meesurements. T. B. Moullin. 2d edition. 1931. J. B. Lipoincott, 227 South 6th St., Philadelphia, Pa. \$312.50.

Radio-frequency electrical mesurements. H. A. Brown. 1931. McGraw-Hill Book Co., Inc., 330 W. L2nd st., New York, N.Y. $\$ 4.00$.

High-Irequency mersurements. A. Hund. 1933. MeGraw-Hill Book Co., Inc., $330 \mathrm{~m}$. 42nd Street, New York, N.Y. 
1933 Report of the Standards Committee of the Institute of Radio Engineers. Institute of Rridio Engineers, 330 W. 42nd st., New York, N.Y.

Inductrnce authority (inductance charts): E. M. Shiepe. 1933. H. Bernard, 135 Liberty. St. New York, N.Y.

Handbook of technical. instruction for wireless telegraphists. H. M. Dowsett. 5th edition. 1934. Iliffe \& Sons, Lta., Dorset House, Stemford st., London, S.E.I, England.

Radio receiver mesurements. R. M. Bernara. 1934. IIiffe \& Sons, Lta., Dorset House, Stamford. St., London, S. T., England.

The mesurement of inductance, capacity and frequency. A. Campbell and 巴. C. Childs. 1935. Mclilien \& Co., Lta., London. 30s.net.

Measurements in radio enginecring. F. F. Terman. 1935. McGrawHill Book Co., 330 W. 42nd St., New York, N.Y. \$4.00...

Engineering handhook of the Nationpl Association of Froadcasters. J. C. McNary. 1936. Published by Netionel Association of Brosdcasters, Netional Press Bldg." Washington, D.C. \$io.00.

Testing radio sets. 3a edition. 1937. Sherwood Press, 552 Edewater Branch, Cleveland, Ohio. \$4.50.

Radio instruments and mesisurements. B.S.Circuler 74.1937 reprint. obtainable from Superintendent of Documents, Government Printing Office, Washington, D.C.: 60 cents per copy.

Vacuum Tibes

The thermionic vecuum tube snd its appication. H. J. Van der Bijl. 1920. McGram-Hill Book Co., Inc., 330 m. 42nd St., NE York. N.Y.

Themionic tubes in radio teiegraphy and telephony. John scott.. Tageart. 1921. Wireless Press, Lta., London, Ingland. Also 326 Broedwav, New York, N.Y.

Elementary textbook on wirezess vacuum tukes. John Scott-Taggart. 1922. Wireless Press, Lta., London, Englana. Also 326

Bropdway, New York, M. Y.

Theory of thermionic vroum tube circuits. I. J. Peters. 1927. MeGrav-Ill Book Co., Inc., 330 W. 42nd st., New York, N.Y. 
LC513 $\cdots 2 / 8 / 38$.

Mlectron tubes and their application. J. H. Morecroft. 1933. John Wiley \& Sons, Inc., 440 Fourth Ave., New York, N.Y. 慗4.50。

Theory of thermionic vacuum tubes. $\Xi$. L. Chaffee. 1933. MeGrammil Book Co., Inc., 330. H. 42nd St, New. York, N.Y. 留 6.00 .

Electronics. R. G., Hudson, 1933: John Wiley \& Sons, Inc., 440 Fourth Ave., New York, N. N. 患2:00。

Electron tubes in industry. K. Henney. 1934. McGraw-Hill Book Co., Inc., 350 $\mathrm{H}$. 42na St., New York, N.Y. $5.00 \ldots$

Electrons at work. C. R. Underhill. 1934. INCGram-Hill Book Co., Inc., 330 w. 42 nd St., New York, N: Y: 33.00 .

The physics, of.electron tubes. I. R. Koller. 1934. Maraw-Hill . Book Co, Inc., 330-W. 42nd st., Nen York, N.Y. $\$ 3.00$.

Thermionic emission. A. L. Reimnn. 1934. John Viley \& Șons, Inc., 440 Fourth Ave., New York, N.

Industrial eleotronics. F. H. Gullixsen \& E. H. Vedder. 1935. John Wilev. \& Sons, Inc., 440 Fourth Ave., New York, N.Y. 㱏3.50.

Electronics and electron tubes. Đ. D. IncArthur. 1936. John, Wiley \& Sons, 440 Fourth Ave., Ner York, N.Y. 2.50.

Fundamentias of engineering electrons. W. Dow. 1937. John Wiley \& Sons, 440 Fourth Ave., IJew York, N.Y. 5.00 .

Photoelectric Phenomens.

Photocelis and theip appications. Zworyin and ilson. 1932. ?d edition. John Viley \& Sons, Irre, 440 Fourth Ave., New York, N.Y. 2.50 .

Photólectric phenomena. A. I. Hughes and L. A. Du Bridge. 1933. McGraw-Hill Book Co., Inc., $330 \mathrm{~m}$. 42na st., Nex York, N.Y. 出 5.00 。

Photoelectric cells; their properties, use and applications. N. R. Cempbell and Dorothy Ritchie. Sir I. Pitmen \& Sons, Lta., New York, N.Y. 3a edition. 1934. 3.75.

Photoelectric cell applications. R. C. Valker and T. M. C. Lenee. 2nd edition. 1935. Pitman Publishing Corp.; 2 West 45 th st., New York, N.Y. 2.50. 
LC513 $\div 2 / 8 / 38$.

Television

Television: H. H. Sheldón and I.N.Grisemóod. "1929. D. Van Nostrand Co., New York, N.Y. \$2.75.

Television.-. Its methods and uses.' E. H. 'Felix. '1932. 'McGrawHill Book Co., Inc., 330"W.42nd'st., New York, N.Y. \$2.50.

First principles of telévision: A. Dinsdale. 1932. John Wiley \& Sons, Inc., $440^{\circ}$ Fourth Avé, New York, N.Y. 霄3.50。

The outlook for tèlevision: O. E: Dunlap. 1932. Harper \& Bros., 15 E.26th St., Ném York, N.Y. 3.00 .

Television - Today and tomorrow.'S: A. Moseley and H. J. BartonChapple. 1934. Sir Isaac Pitmar \& Sons, Ltd., Loridon,' England.

Television, theory and practice. J.H. Rayner. 1934. Chapman and Hall, London. I2s.6a.

Television (Collected adaresses and papers on the future of the new art and its redent technical developments), vol.1, July 1936; vol.II, 1937. RCA Institute's Technicel Press, 75 Varick St., New York City:

Television with cathode-rays (loose-leaf). A. H. Halloran. 1936. Radio Lta., 7460 Beverly Blva., Los Angeles, Calif. \$2.75.

Television optics - An introduction. L. M. Myers. Pitmen Publishing Co., New York City. 1937. 8.50 .

Television technical terms and definitions. E.J.G.Lewis. 1937. Fitman Publishing Corp., 2 ' 45 th St., New York, N.Y. \$1.75.

Television engineering. J. C. Wilson. Pitman Publishing Corp., 2 w. 45th st., New 'Yorly, N.Y. I937. " 10.00 .

Servicing Radio Equipment

Servicing auto-radio receivers. J. F. Rider. Radio Treatise Co., Inc., 1440 Broadway, New York, N.Y.

Radio service questions and answers. J. F. Rider. 2 volures. Radio Treatise Co., Inc., 1440 Brodidway, New York, N.Y.

Practical radio reparing hints. J. F. Rider. Radio Treatise Co., Ine., 1440 Broadway, New York, N.Y.

Iractical testing systems. J. F. Rider. 1930. Ridio Treatise Co., Inc., 1440 Broadway, New York, N.Y. N.00。 
LC513... 2/8/38.

Radio Servicing Course. A. A. Ghersrai and B. M. Freed. 1930. Radio Technical Pub. Co., 45 Astor Place, New York, N.Y. 31.50.

servicing receivers by means of resistance measurements. J.F.' Rider. 1932. Rodio Treatise Co., Inc., 1440 Broadway' New. York, N.Y.

Servicing superheterodynes. J. F. Piider. Revised edition 1934. Radio Treatise Co., Inc., 1440 Broadway, New York, N.Y.

Specialized auto radio manual: Vol.I. J.F.Rider. 1933. Rado Treatise Co., Inc., 1440 Brordway, New York, N.Y. \$3:50; vol.2.

Practical radio construction and repairing - Redio receiving tubes - Practical radio. - All three of these books by lloyer and Wostrel. 1934. Published by McGraw-Hill:Book Co., Inc., 330 W. 42nd st., New York, N.I. Frice for three, 7.50.

Perpetual trouble shooter's manual. J.F. Rider. 6 volumes. 1935. Radio Treatise Co., Inc:, 1440 Broedway, New York, N.Y. VOI:I, 37.50 ; VOI.2, 6.50 ; VOI. $3,37.50$; VOI.4; 7.50 ;

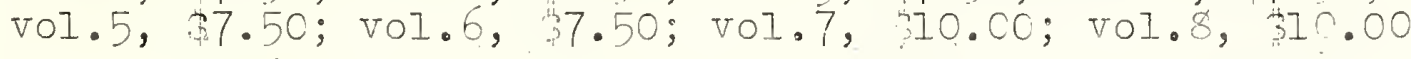
Official radio service manual. I931, 34.50; $1932, \cdot 35.00$;

1933, 皮5.00; 1934, 3.50; 1935, 37.00. Gelnsback Fublisations, Ine., 99 Hudson st., New York Gity.

Auto-radio service manual and supplement. 1936. 32.50. Gernsback Publications Inc.; 99 Huason St., Ner York City.

Wireless servicing manuel. W. T. Cocking. 3ra edition. 1937. Ilitée \& Sons, Lta., London, Englend. 58: net.

Miscellaneous

How to pess.U.S.Goveriment radio ricense examinations. John Wiley \& Sons, Inc., 440 Fourtin Ave., New York, N.Y. 2.00.

Rado traffic manuel fnd opereting regulations. Duncan \& Drew. John Wley \& Sons, Inc., 440 Fourth Ave., New York, N.Y. h2.00.

Useful radio tables. J. F. Rider. Radio Treatise Co., Inc., 1440 Broadway, New Vork, N.Y.

Wireless direction finding and directional reception. 2 d edition. R. Keen. 1927. Iliffe \& Sons, Lta., Dorset House, Stamford st., London, Englend. 
Electrical condensers. P. R. Coursey. 1927. Sir I. Pitman \& Sons, Ltd., London, England.

Quartz resonators and oscillators. H. Vigoureux. 1931'. Obitainable from British Library of Information, 270 Madison Ave., New York, N.Y.

High-frequency alternating clurrents. K. INCIlwain and J.G. Brainard. 1931. John Wiley \& Sons, Inc., 440 Fourth Ave., New York, N.Y. 6.00 .

The cathode-ray oscillograph in radio research. $R$. A. WatsonWatt, J.F.Herd, L. H. Baink ridge-Bell. 1933. Published by H.M. Stationery office, London, England. Obtainable from

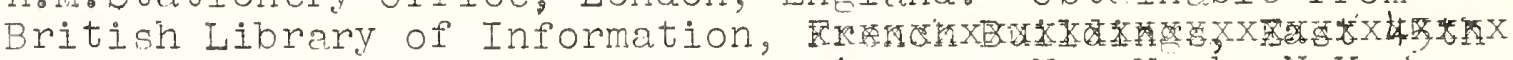

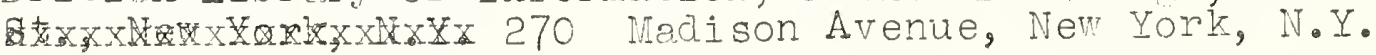

Applied acoustics. H. Folson and F. Massa. 1934. P. Blakeston's Stone \& Co., Inc., 1012 Walnut St,, Philadelphia, Pa. 汸4.50.

Electric circuits and wave filters. A. T. Starr. 1935. Pitman Publishing Corp., $2 \mathrm{~W}$. 45th St. New York City. \$6.00.

The cathode-ray tube at work. J. F. Rider. 1935. J.F. Rider, Publisher, 1440 Broadway, New York City. 2.50 .

Making a living in radio. Zeh Bouck. 1935. McGraw-Hill Book Co., $330 \mathrm{~W}$. 42nd st., Ner York, N.Y. T2.00.

Radio data charts. R. T. Beatty. 1936. Iliffe cons, Ltd., Dorset House, Stamford St., London, S. E.I, England.

Radio operating questions and answers. 6th ed. 1937. Nilson \& Horning. MeGraw-Hill Book Co., Inc., 330 W. L2nd st., New York, N.Y. :2.50。

Radio interference and its suppression. J.H. Reyner. Sherwood Press, Box 552, Edgewater Branch, Cleveland, Ohio. 1937.

4.00 .

Radio field service data (loose-leaf). A. A. Gherardi. Radio \& Tech. Publishing Co., New York, N:Y. 1937. B2.50.

3. U. S. Government Radio Publications

A large number of papers on radio subjects have been issued by the National Burenu of Standards. Some of these have been published by the Government Printing office and some in various periodicals. Most of them are of interest primarily to the radio engineer or scientist. A list of the current radio publications 
can be secured by addressing a request to the Nationsl Bureau of Standards, Washington, D.C. News of the Bureau's radio work, and announcements of new publications, are given in "Technical News Bulletin", a montily publication which may be obtainea by mail in the U. S. for 50 cents per year from the superintendent of Documents, Government Frinting office. The notices. of new publications state the prices at which each may be purchased from the Superintendent of Documents. The publications of the National Bureau of standards cover many subjects, including, besides radio, electricity, light, sound, heat, chemistry, metellurgy, engineering materials, stanärds of weight and measure, and many other scientific and technical subjects.

A book, "International Radiotelegraph Conference, Madrid, 1932", giving the International Telecommunication Convention and Radio Regulations (published by the state Dept.) may be obtained for 30 cents from the Superintendent of Documents, Government Printing office, Wàshíngton, D.C. tions.

See also Section 5 below for other Government radio publica-

4. Publications of International Bureau of the Telecommunication Union, Berne, Switzerland.

The following radio station lists are available from the International Bureau, at the prices. statea.

List of freduencies, and supplements. (2l swiss gold francs, including postage)

Iist of coast stations and ship stations. (4 Smiss gold Proncis, including postage).

List of aircraft and aeronautical stations. ( 2.75 Swiss gold francs, including. postage).

List of broadcasting stations, and supplements. (4.25 Swiss soldirancs, incluaing postage).

List of stations performing special services, and supplements. (5.50 swiss Eo?d francs, including postage).

List of call letters of fixed, land, and mobile. stations, and suoplements: (10 Swiss gold francs, incluaing postage). postage).

List of fixed stations: (7.70 Swiss gold francs, including 
Remittance should be made by international money order to the International Bureau of the Telecommunication Union, Berne, Switzerland.

\section{Radio Lavis and Regulations}

The law provides that in order to operate any radio transmitting station, both a station license and an operator license must be secured. The lam provides severe penalitis for the operation of a transmitting station without proper licenses.

A station used only for receiving does not require a station license. operators of stations used only for receiving do not require operators' licenses, but must maintain secrecy in regard to messages heard, other than broadcast messages.

Information and the necessary application blanks for transmitting station and operator licenses are obtainable from the Federal Communications Commission, Washington, D. Co, or the field office of the Commission in the district in which the applicant resides.

Radio District No.I- (Inciudes: Connecticut, Maine, Massachusetts, New Hampshire, Rhode Island and Vermont). Address: Inspector in Charge, Federal Communications Commission, Customiouse, 7th Floor, Boston, Mass.

Radio pistrict No.2.- (Includes: The Counties of Albany, Bronx, Columbia, Delamare, Dutchess, Greene, Kings, Nassau, Orange, New York, Putnam, Queens, Rensselaer, Richmonä, Rockland, Schenectady, Suffolk, Sulivan, Ulster, and Westchester of the state of New York, and the Counties of Bergen, Essex, Hudson, Hunterdon, Nercer, Midalesex, Monmouth, Morris, Passaic, Somerset, Sussex, Union and Warren of the State of New Jersey). Adaress: Inspector in Charge, Federal Communications Commission, 1024-1026-1030 Federal Blag., 641 Washington st., New York, N.Y.

Radio District No.3.- (Includes: Adams, Berks, Rucks, Carbon, Chester, Cumberlard, Dauphin, Delaware, Iuncaster, Lebanon, Lehigh, Monroe, Montfomery, Northampton, Perry, Philadelphia, Schuylkill, and York of the state of Pennsylvania, and the Counties of AtIantic, Burlington, Camaen, Cape May, Cumberland, Gloucester, Ocean, and Snlem of the State of New Jersey; and the County of Newcastle, State of Delaware). Address: Inspector in Charge, Federal Communications Commission, Room I200, New U.S.Customhause, 2nd and Chestnut sts., Philadelphia, Pa.

Radio District No.4.- (Includes: The state of Maryland, the District of Columbia, and the Counties of Arlington, Clark, Fairfax, Fauquier, Frederick, Loudoun, Page, Prince William, Rappahannock, 
Shenandoah, and Warren of the state of Virginia, and the Counties of Kent and Sussex, of the stete of Delaware). Adaress: Inspector in Charge, Federal Communications Commission, Fort McHenry, Baltimore, Md.

Radio District No.5.- (Includes: The State of Virginia, except the counties of Arlington, clark, Frirfax, Fauquier, Frederick, Loudoun, Page, Prince William, Rappahannock, Shenandoah, and Warren; and the State of North Carolina except the Counties of Ashe, Avery, Buncombe, Burke, Caldwell, Cherokee, Clay, Cleveland, Graham, Haywood, Henderson, Jackson, NcDowell, Macon, Madison, Mitchel.1, Polk; Ruthérora, Swain, Transylvania, Watauga and. Yancy). Adaress: Inspector in Charge, Federal communications Commission, Room Ho2, New Post Office Builaing, Norfolk, Va.

Radio District No.6.- IIncludes: The states of Alabama, Georgia, South Carolina, Teinessee, and the Counties of Ashe, Avery, Buncombe, Burke, Caldwell, Cherokee, Clay, Cleveland, Graham; Haywood, Henderson, Jackson, McDowel1, Macon, Madison, Mitchell, Polk, Rutherford, Swain, Transylvania, Watauga and Yancy of, the State of North Carolina. Aadress: Inspector in Charge, Federal Communications Commission, 4li Federal Annex, Atlanta, Ga. Sub-office.- Address: Raio Inspector, Federal Communications Commission, 208 Postoffice BIde., Savannah, Gá.

Radio District No. 7.- (Includes: The State of. Florida). Adaress: Inspector in Charge, Federal Communications Commission, Post office Box 150, Niami, Fla. Sub-office: Address: Redio Inspector, Federal Communications Commission, 201 stovalls Professional Bldg., Tampa, Fla.

Radio District No.8.-. (Includes: The states of Arkansas, Louisiana, Mississippi, and, the City of Texariara only of Mexas). Address: Inspector in Charpe, Federal. Communications Commission, 326 Customhouse, New Orleans, La.

Radio District No. 2.- (Includes: The Counties of Aransas, Bra- . 7oria, Brooks, Calhoun, Cameron, Chambers, Fort Bend, Galveston, Goliad, Harris, Hidalgo, Jackson, Jefferson, Jim Wells, Kenedy; Kleberg, Mentagoraa, Nueces, Refugio, San Patricio, Victoria, Wharton, and Willacv of the state of Texas). Adaress: Inspector in Charge, Federal Communications Comission, 404 Federal Building, Galveston, Texas.

Radio District No. 10.- (Includes: The state of Texas, except the Counties of Aransas, Brazoria, Brooks, Calhoun, Cameron, Chambers, Fort Bend, Galveston, Goliad, Harris, Hidalgo; Jacrson, Jefferson, Jim Welis, Kenedy, Kleberg, Natagoraa, Nueces, Refugio, San Patricio, Victoria, Wharton, and Yancy, and the City of Texarkana, and the 
States of New Mexico and Oklahoma). Address: Inspector in Charge, Federal Communications Commission, 302 U.S. Terminal Annex Bldg., Dallas, Tex.

Radio District No. 11.- (Includes: The State of Nevada, Arizona, and the Counties of Imperial, Kern, Los Angeles, Inyo, Orange, Riverside, San Bernardino, San Diego, San Luis Obispo, Santa Barbara, and Ventura of the state of California). Address: Inspector in Charge, Federal Communications Commission, 1105 Rives-Strong BIdg., Los Angeles, Calif. Sub-office. - Address: Radio Inspector, Federal Communications Commission, Room 503, New California Builaing, San Diego, Calif.

Radio District No. 12.- (Includes: the state of California, except tin sounties of Imperial, Kern, Los Angles, Inyo, Orange, Riverside, San Bernardino, San Diego, San Luis Obispo, Santa Barbara, and Ventura; the State of Nevada, except the County of Clerk; and Guam, Midway, and American Samoa). Address: Inspector in Charge, Federal Communications Commission, 328 Customhouse, San Francisco, Calif.

Radio District No. 13.- (Includes: the state of oregon and the State of Idaho, except the dounties of Benewah, Bonner, Boundary, Clearwater, Idaho, Kootenai, Latah, Lewis, Nez Perce, and Shoshone). Adaress: Inspector in Charge, Federal Communications Commission 207 New U.S.Courthouse, Portland, Oregon.

Radio District No. 14.- (Includes: Alaska; the state of Weshington, the Counties of Benewah, Bonner, Boundary, Clearwater, Idaho, Kootenai, Latah, Lemis, Nez Perce, and Shoshone of the state of Idaho, and the Counties of Beaverhead, Broadwater, Cascade, Deerlodge, Flathead, Gallatin, Glacier, Granite, Jefferson, Lake, Lewis, and Clark, Lincoln, Madison, Meagher, Mineral, Hissoula, Ponders, Powell, Ravalli, Sanders, Silver Bow, Teton, and Toole of the State of Montana). Adaress: Inspector in Charge, Federal Communications Commission, 808 Federal Office Bldg., Seattle, Wash. Sub-office. - Address: Radio Inspector, Federal Communications Commission, P.O.Box 2719, Juneru, Alaska.

Radio District No. 15.- (Includes: The States of Colorado, Utah, Wyoming, and INontana, except the Counties of Beaverhead, Broadwater, Cascade, Deerlodge, Flathead, Gallatin, Glacier, Granite, Jefferson, Lake, Lewis and Clark, Lincoln, Madison, Meagher, Mineral, Missoula, Ponders, Powell, Ravalli, Sanders, Silver Bow, Teton, and Toole). Address: Inspector in Charge, Federal Communications Commission, 504 Customhouse, Denver, Colo. 
Radio District No. 16.- (Ineludes: The States of North Dakota, South Dakota; Ninnesota, and the Counties of Alger, Baraga, Chippewa, Delta, Dickinson, Gogebic, Houghton, Iron Keeweenaw, Luce, Mackinac, Marquette, Menominee, Ontonagon, and Schoolcraft of the state of Michigan, and the state of Wisconsin, except the Counties of Columbia, Crawford; Dane, Dodge, Grant, Green, Iowa, Jefferson, Kenosha, Lafayette, Milwaukee, Ozaukee, Racine, Richland, Rock, Sauk, Walworth, Washington, and Waukesha). Address: Inspector in Charge, Federal Communications Commission, 927 Main Post office. BIdg., St. Paul, Minn.

Radio' District No. 17.- " (Includés: 'the States of Nebraska, Kansas, Missouri, and Iowa, except the Counties of Allamakee, Buchanan, Cedar, Clayton, Clinton, Delawaire, Des Hoines, Dubuque, Fayette, Henry, Jackson, Johnson, Jones, Lee, Linn, Louisa, Muscatine, Scott, Washington, and Winneshiek). Address: Inspector in Charge, Federal Communications Cammission, 609 Pickmick Bldg., 903 McGee St., Kansas City, Mo.

Radio District No. 18.- (Includes: the states of Indiana, Illinois, and the Counties of Allamakee, Buchanan, Cedar, Glayton, Clinton, Delware; Des Moines, Dubuque, Fayette, Henry, Jackson, Johnson, Jones, Lee, Linn, Louisa, Muscatine, Scott, Washington, and Winneshiek of the State of Iowa; and the Counties of Columbia, Crawford, Dane, Dodge, Grant, Green, Iowa, Jefferson, Kenosha, Lafayette, Milwaukee, Ozaukee, Racine, Richland, Rock, Sauk, Walworth, Washington and Waukesha of the State of Wisconsin). Address: Inspector in Charge, Federal Communications Commission, 246 U.S. Courthouse Bldg., Chicago; IIl.

Radio District No. 12.- (Includes: The State of Michigan, except the Counties of Alger, Baraga, Chippewa, Delta, Dickinson, Gogebic, Houghton, Iron, Keeweenaw, Luce, Mackinac, Marquette, Nenominee; Ontonagon and Schoolcraft; the States of ohio, Kentucky, and West Virginia). Address: Inspector in Charge, Federal Communications.Commission, 1025 New Federal Bldg., Detroit, Mich.

Radio District No. 20.- (Includes: the state of New York, except the Counties of Albany, Bronx, Columbia, Delaware, Dutchess, Greene, Kings, Nassau, New York, Oranee, Putnam, Queens, Rensselaer, Richmond, Rockland, Schenectady, Suffolk, Sullivan, Ulster, and Westchester; the State of Pennsylvania, except Adams, Berks, Bucks, Carbon, Chester, Cumberland, Dauphin, Delaware, Lancaster, Lebanon, Jehigh, Monroe, Montgomery, Northempton, Perry, Philadelphia, Schuylkill, and York). Address: Inspector in Charge, Federal Communications Com ission, 514 Federal Bldg., Buffalo, N.Y. 
Radio District No. 2l.- (Incluades Territory of Hawaii). Adaress: Inspector in Charge, Federal Comminications Commission, Aloha Tower, Honolulu, T.H.

Radio District No. 22.- (Includes: The .Island of Puerto Rico and the Virgin Islands). Adaress: Inspector in Charge, Federel Communications Commission, 303 Ochoa Bldg., San Juan, P.R.

Thie Commission also has the two following field oftices: Inspector in Charge, Federal Communications Commission, Central Frequency Monitoring Station, P. O. Box 788, Grand Island, Neb.; Inspector in Charge, Federal Comminications Commission, Haval Training Station, Radio Station Bldg., Great Lakes, Ill.

Examination for: radio operators' licenses are held in the district offices listed above and in addition at:

Washington, D.C. Schenectady, N.Y. Winston-Salem, N.C. Nashville, Tenn。
San Antonio, Tex. OkI ahoma City, OkIa.

Des. Proinog, Iowa:。 st. Louis, Mo.

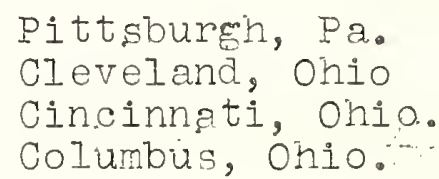

Pittsburgh, Pa. Cleveland, Ohio Columbus, Ohio.

\section{Safety Rules.}

All' ordinary precautions required for the safe operation of any electrical equipment should be observed in every raido strtion; for example, all high-voltage wiring should be carefully insulated and kept as far as possible from other wiring and so placed as to minimize the possibility that persons may oome in contact with it, and suitable danger tags should be displayed:

Insurance compenies and eity governments make certain requirements regarding electrical installations in builaings. The usual requirements are summarized in a small book, the Mational Electrical Code, which may be secured for five cents from the National Board of Fire Underwriters, 85 John Street, New York, N.Y. Article 310 of this Code gives the requirements for radio equipment.

Requirements for safe redio construction are given in Netional Bureau of Standards Handboor H9, "Safety Rules for Rrdio Installations," which may be obtained from the superintendert of Documents, Government Printing Office, Washington, D.C., at ten cents per copy. This handbook gives, on proges. 7 to 14, rules for erection of antennas. 'Some explanation of these rules and of the reasons for them'is given in Part 5 of the N.B.S. Handbook H4, "Discussion of the National Electrical Safety Code", the price of which is \$1.00. 
LC513 - - 2/8/38.

Safety standards for radio transmitting equipment are given in the Report of the Standards Comittee, obtainable from the Institute of Radio Engineers, 330 West 42nd St., New York, N.Y.

Department of Commerce, Washington, D.C. 
